\title{
GMR
}

\section{Agronomic performance of plantain genotypes and genetic variability using Ward-MLM algorithm}

\author{
Z.S. Gonçalves ${ }^{1}$, D.R. S. da Invenção ${ }^{1}$, C.A. Da S. Ledo ${ }^{2}$, C.F. Ferreira ${ }^{2}$, E.P. Amorim ${ }^{2 *}$ \\ ${ }^{1}$ Universidade Federal do Recôncavo da Bahia (UFRB), Centro, 44380-000, Cruz das Almas, \\ Bahia, Brazil \\ ${ }^{2}$ Embrapa Mandioca e Fruticultura - Rua Embrapa, s/n CP 007, Centro, 44380-000, Cruz das \\ Almas, Brazil
}

Corresponding author: E. P. Amorim

E-mail: edson.amorim@embrapa.br

Genet. Mol. Res. 17 (1): gmr16039882

Received January 14, 2018

Accepted February 20, 2018

Published February 24, 2018

DOI http://dx.doi.org/10.4238/gmr16039882

Copyright (C) 2018 The Authors. This is an open-access article distributed under the terms of the Creative Commons Attribution ShareAlike (CC BY-SA) 4.0 License.

\begin{abstract}
Plantains in Brazil are produced from the 'Terra Maranhão', 'Terrinha' and 'D'Angola' cultivars, which are all susceptible to black Sigatoka, weevils and nematodes. Therefore, the development of resistant plantain cultivars with agronomic characteristics aligned with market demands is the most efficient way to overcome these barriers regarding fruit production. The objectives of this work were to evaluate plantain cultivars for agronomic and physicochemical characteristics, and to estimate their genetic variability using ISSR molecular markers. The experimental design used was randomized block with ten plantain genotypes distributed in five blocks with four plants per plot. Ten agronomic and five physicochemical characteristics were measured. The agronomic, physicochemical and molecular (ISSR) characteristics were analyzed together using the WardMLM algorithm. Based on the agronomic and physicochemical evaluations, the 'Red Yad', 'Curare Enano' and 'Chifre de Vaca' genotypes could potentially be recommended to farmers, especially due to their short height and higher bunch mass and number of hands. The analysis of the combined data using the Ward-MLM algorithm identified genetic variability that, although restricted, can be used for genetic improvement strategies. To the best of our knowledge this is the first work that validates new plantains under Brazilian conditions, increasing cultivar options for farmers.
\end{abstract}

Key words: Selection; Genetic improvement; Gower distance; Musa spp., ISSR markers 


\section{INTRODUCTION}

Bananas and plantains stand out in world production for being among the eight most important foods and the fourth most important in Africa (Seydou et al., 2017). World production in 2014 was approximately 145 million tons with a gross value of production (GVP) reaching 52 billion dollars (FAO, 2017). Plantains differ from bananas basically because they contain more starch and are also prepared differently; they are cooked or fried and not very palatable when raw (Borges et al., 2014). No statistical information is available about plantain production in Brazil because it is mixed with banana data; there is no clear distinction between banana and plantain production. It is estimated that plantains account for $10 \%$ of Brazilian production of Musa spp., which corresponds to approximately 700 thousand tons per year (Arantes et al., 2017). Although plantains are important in Brazil, only three cultivars are available to farmers, 'Terra Maranhão', 'Terrinha' and 'D'Angola', which are all susceptible to black Sigatoka, weevils and nematodes (Tripathi et al., 2015; Kamira et al., 2016; Castañeda et al., 2017). For a genetic improvement program to be successful, the existence of genetic variability of characteristics of interest is fundamental. Based on this premise, agronomic and physicochemical characterization of plantain germplasms, associated with the use of DNA markers, can provide useful information to improve fruit crops and to identify genotypes with potential to use in crosses with improved diploids that are disease resistant, especially to black Sigatoka (Amorim et al., 2013). ISSR markers use repetitive simple sequence primers to amplify regions between target sequences. The present work evaluated plantain genotypes from the germplasm collection at Embrapa Mandioca e Fruticultura for agronomic and physicochemical characteristics, with the goals of identifying plants that can be directly recommended to framers and to use in crosses to develop hybrids, and estimated genetic variability using combined multivariate methods and ISSR molecular markers. To the best of our knowledge this is the first work that validates new plantains under Brazilian conditions, increasing cultivar options for farmers.

\section{MATERIAL AND METHODS}

\section{Genetic material and experimental design}

The study was conducted in the experimental field in the city of Cruz das Almas, State of Bahia, Brazil (1240'19"S, $39^{\circ} 06^{\prime} 22^{\prime} \mathrm{W}^{\prime}, 220 \mathrm{~m}$ above sea level), between October 2013 and December 2015, including two production cycles. The climate is designated as tropical hot and humid, Aw to Am, according to the Köppen classification, with an average annual temperature of $24.5^{\circ} \mathrm{C}$, relative humidity of $80 \%$, and rainfall of $1,250 \mathrm{~mm}$. The plants were maintained in a family structure (mother plant, child, grandchild) per group; extra shoots were mechanically removed. Culture treatments, such as defoliation, support, cutting of the pseudostem to shorten it after harvesting, removal of the male rachis, irrigation and picking of weevils, were performed every 15 days using standard procedures.

The experimental design was in randomized blocks with ten plantain genotypes distributed in 5 blocks with four plants per plot, including five of the False Horn type (Tipo Velhada, D’Angola, Curare Enano, Samura B and Terra Anã Branca), three of the French type (Terra Sem Nome, Red Yade and Pinha) and two of the Horn type (Chifre de Vaca and Mongolo).

\section{Agronomic and physicochemical evaluations}

The evaluations of the agronomic and physicochemical characteristics were conducted with all the plants used in the experiment during two production cycles: plant height - PHT (m), measured from the base of the pseudostem to the insertion of the last leaf with a tape measure; pseudostem diameter - PDI $(\mathrm{cm})$, measured $30 \mathrm{~cm}$ above the base of the pseudostem using a pachymeter; number of live leaves during flowering - NLF, live leaves that had a minimum of $50 \%$ of their area still photosynthesizing; number of live leaves at harvest - NLH; number of days from flowering to harvestNFH, number of days from planting to flowering- NPF; number of days from planting to harvest - NPH; bunch mass MSB (kg), weighed with a digital scale; mass of the second hand- MSH; number of hands - NHS; total number of fruits per bunch - NFB; number of children per plant- NCP, mass of the fruits of the second hand- MFH; fruit length FTL (cm); fruit diameter - FTD (cm); Pulp mass- PUM (g); pulp / peel ratio- PPR (\%); pulp yield- PUY (\%); pulp diameter- PUD (cm); thickness of the peel- TOP (mm); pulp firmness - PUF (LB), evaluated with a penetrometer in pounds; titratable acidity - TIA (\%); soluble solids - SS ( ${ }^{\circ}$ Brix); and ratio (SS/AT). After the firmness analysis, the pulp was shredded up in a blender and water was added in the proportion of 1:1. This was then used for the titratable acidity - TIA (\%) and soluble solids - SS analyses (Dadzie et al., 1997).

The normality of the data was tested, followed by the analysis of variance. The genotypes were grouped using the Scott and Knott test. 


\section{DNA extraction and amplification}

Young plantain leaves were collected and freeze dried. The CTAB (Cetyltrimethylammonium bromide) Doyle and Doyle (1990) protocol was used for DNA extraction. Fifteen ISSR primers were used for the molecular characterization of the plantain genotypes (Table 1).

Table 1. Order, names, and sequences of the 15 ISSR primers used in the genetic diversity analysis of the 10 plantain genotypes.

\begin{tabular}{lrr}
\hline Primers & Name of primer & $\left.\mathbf{( 5}^{\prime} \mathbf{- 3}^{\prime}\right)$ \\
\hline $\mathbf{1}$ & Tri CAG 3' YC & CAGCAGCAGCAGCAGYC \\
\hline $\mathbf{2}$ & Tri CGC 3' RC & CGCCGCCGCCGCCGCRC \\
\hline $\mathbf{3}$ & Tri CGG 3' RC & CGGCGGCGGCGGCGGRC \\
\hline $\mathbf{4}$ & Tri GTT 3' RC & GTTGTTGTTGTTGTTRC \\
\hline $\mathbf{5}$ & Tri GTC 3' RC & GTCGTCGTCGTCGTCRC \\
\hline $\mathbf{6}$ & DIGT 5' CR & CRGTGTGTGTGTGTGTGT \\
\hline $\mathbf{7}$ & Tri TAC 3' RC & TACTACTACTACTACRC \\
\hline $\mathbf{8}$ & Tri CTT 3' RC & CTTCTTCTTCTTCTTRC \\
\hline $\mathbf{9}$ & Tri CCG 3' RC & CCGCCGCCGCCGCCGRC \\
\hline $\mathbf{1 0}$ & Tri GAT 3' RC & GATGATGATGATGATRC \\
\hline $\mathbf{1 1}$ & Tri CAC 5' CR & CRCACCACCACCACCAC \\
\hline $\mathbf{1 2}$ & Tri GTG 3' RC & GTGGTGGTGGTGGTGRC \\
\hline $\mathbf{1 3}$ & Tri GTG 5' CR & CRGTGGTGGTGGTGGTG \\
\hline $\mathbf{1 4}$ & Tri GTG 5' CY & CYGTGGTGGTGGTGGTG \\
\hline $\mathbf{1 5}$ & Tri GAC 3' RC & GACGACGACGACGACRC \\
\hline & &
\end{tabular}

The amplification reactions were made at a final volume of $25 \mu \mathrm{L}$, with the following reagents: $50 \mathrm{mM} \mathrm{KCl,} 10 \mathrm{mM}$ Tris- $\mathrm{HCl}$ (pH 8.3), $2.0 \mathrm{mM} \mathrm{MgCl} 2,0.5 \mu \mathrm{M}$ of each of the dNTPs (dATP, dTTP, dGTP, dCTP) at a concentration of 0.2 $\mathrm{mM}, 0.5 \mu \mathrm{M}$ of each primer, $30 \mathrm{ng}$ of genomic DNA and one unit of Taq DNA polymerase (Invitrogen, EUA). The amplifications were carried out in an Applied Biosystems Veriti 96-Well Thermal Cycler using the following program: initial cycle of $3 \mathrm{~min}$. at $94^{\circ} \mathrm{C}$, followed by 39 cycles of $45 \mathrm{~s}$ at $94^{\circ} \mathrm{C}$, equal temperature for all the primers $\left(48^{\circ} \mathrm{C}\right)$ for $45 \mathrm{~s}, 1.00 \mathrm{~min}$. of extension at $72^{\circ} \mathrm{C}$, and a final extension of $7 \mathrm{~min}$ at $72^{\circ} \mathrm{C}$, with a storage temperature of $14^{\circ} \mathrm{C} \infty$.

\section{STATISTICAL ANALYSIS}

\section{Agronomical and physicochemical data}

The destructive analyses were made with the second hand at maturation stage 6 from three randomly chosen fruits, according to the Association of Official Analytical Chemists - AOAC (1997).

\section{Molecular analysis}

Genotyping was conducted with the Fragment Analyzer ${ }^{\mathrm{TM}}$ Automated CE System (Advanced Analytical) according to the manufacturer's protocol and the binary data matrix was obtained using the software PROSizeTM. The data was considered as (1) presence and (0) - absence of band and the distance matrix obtained using the Jaccard index coefficient.

The agronomic, physicochemical, and molecular (ISSR) data were combined using the Ward-MLM algorithm. To compare the groups, the Cluster and IML procedure (Interactive Matrix Programming) was used in the SAS program (Statistical Analysis System, version, 9.0). The Ward-MLM clustering method was used, considering the combined matrix obtained with the Gower algorithm. To define the ideal number of groups, several cut off points were tested, including the melting point, one which considers the greatest leap and the average genetic dissimilarity among the genotypes (average of the matrix). The statistical analyses were carried out in the SAS (Statistical Analysis System, version 9.0), and $R$ ( $R$ software version 3.4.1.) statistical software.

\section{RESULTS AND DISCUSSION}

The ANOVA of the 10 agronomic characteristics revealed significant differences for the source 'genotype' variation, except for 'number of live leaves during flowering - NLF' and 'fruit length and diameter - FTL and FTD' (Table 2). 

Table 2. Averages for the 15 agronomic characteristics for the 10 plantain genotypes measured during two production cycles.

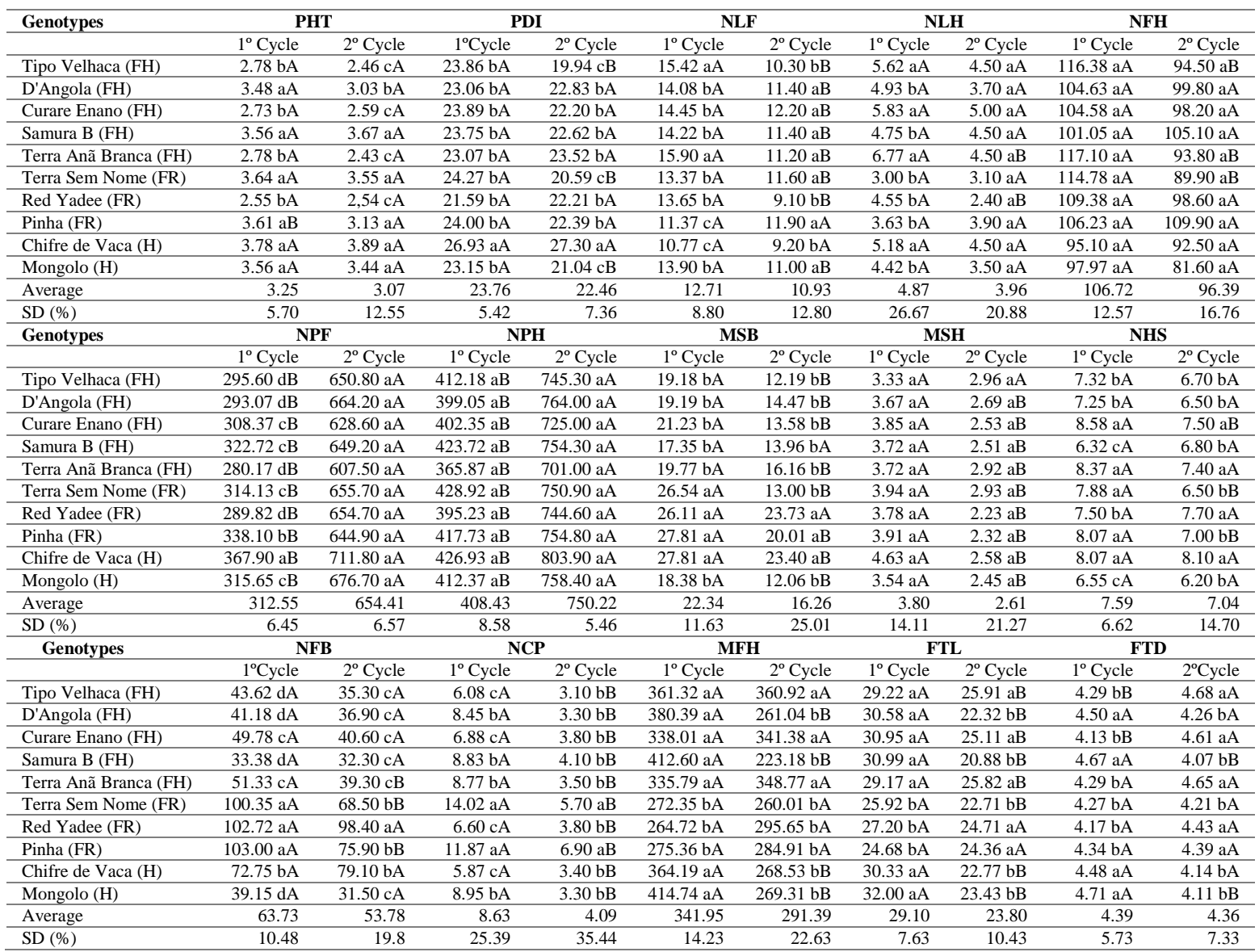

Plant height (PHT -m), pseudostem diameter (PDI -cm), number of live leaves during flowering (NLF), number of live leaves at harvest (NLH), number of days from flowering to harvest (NFH), number of days of planting the flowering (NPF), number of days from planting to harvest (NPH), bunch mass (MSB $-\mathrm{kg}$ ), mass of the second hand (MSH), number of hands (NHS), total number of fruits per bunch (NFB), number of children per plant (NCP), mass of the fruits of the second hand (MFH), fruit length of second hand (FTL - $\mathrm{cm})$, fruit diameter of second hand (FTD - cm). Standard deviation (SD). Averages followed by the same uppercase letters in the horizontal and lowercase letters in the vertical comprise a statistically homogenous group and do not differ among themselves based on the Scott and Knott test, respectively, at 5\% probability. False horn(FH), French (FR), Horn (H). MS (Mean Square) * and **, significant at $1 \%$ and $5 \%$ probability by the F-test.

For the other seven characteristics, from 'plant height - PHT' and 'number of hands and fruits per bunch - NHS and NFB' it was possible to infer that the genotypes tested presented differentiated behaviors. This fact is relevant since the objective of this work is to select at least one genotype with potential to directly recommend to farmers in the region of Recôncavo da Bahia and/or to use in crosses with improved diploids. The two cycles used to measure the agronomic performance of the plantains were significant for all characteristics except 'fruit diameter - FTD'. Cycles are considered a way of conducting the genotypes because the species is vegetatively propagated and the offspring/children move into production after harvesting the bunch and cutting the mother plant. Therefore, it is possible to confirm that there is variation for the characteristics considered for the mother plant and its respective offspring/child for each of the genotypes individually phenotyped. The 'genotypes vs. cycles' interaction was significant for $50 \%$ of the measured characteristics, indicating that, on average, there were behavioral differences between the plants of the first and second production cycles (Table 2). Due to this result, the data from the second cycle are discussed because it allows for the selection of genotypes with more potential to recommend to farmers and to use in crosses with diploids to develop new hybrids. The Scott \& Knott grouping method resulted in the formation of three groups for the plant height (PHT) characteristic, with a minimum value of 2.43 meters for 'Terra Anã Branca', a maximum value of $3.89 \mathrm{~m}$ for 'Chifre de Vaca', and a 
general average of $3.07 \mathrm{~m}$ (Table 2). Alvarez et al. (2011) worked with the cultivar 'Curare Enano', in Mexico, and encountered a plant height of de $2.73 \mathrm{~m}$, which is above what was observed in the present study. Kamira et al. (2016), in the eastern part of the Democratic Republic of Congo, worked with the plantains FHIA 21, Obubit and Musheba and observed an average of $2.98 \mathrm{~m}$, which is similar to what was observed in Cruz das Almas $(3.07 \mathrm{~m})$. Short genotypes are preferred by farmers because there is no need for support and the increase in planting density results in greater economic return (Amorim et al., 2013). In this context, 'Tipo Velhaca', 'Curare Enano', 'Terra Anã Branca' and 'Red Yad', are notable.

For pseudostem diameter (PDI), the average was $22.46 \mathrm{~cm}$ and the highest value was for 'Chifre de Vaca' $(27.30 \mathrm{~cm})$ (Table 2). Under conditions in Guanambi (BA), the cultivar 'D'Angola' had a pseudostem diameter close to what was observed in the present study (Faria et al., 2010). In contrast, Alvarez et al. (2011) reported that the cultivar 'Curare Enano' had a pseudostem diameter of $17.5 \mathrm{~cm}$ and Kamira et al. (2016), in the Congo, reported values of $22.10 \mathrm{~cm}$ for the plantains FHIA 21 and Oububit, which is below what was observed under the conditions in Cruz da Almas (Brazil). Pseudostem diameter is related to tipping and/or breaking caused by wind and reflects the ability of the plant to sustain the bunch, and could be inferred based on the genetic variability for this characteristic among the genotypes evaluated (Silva et al., 2016). For this variable, the genotype 'Chifre de Vaca', was notable.

In relation to the number of live leaves during flowering (NLF), an average of 10.93 was observed, with the formation of two groups for the second cycle. Eight of the ten genotypes had a minimum of 10 photosynthetically active leaves. At the harvest, there was a drastic reduction in the NLH, with an average of 3.96. This is probably due to the incidence of black Sigatoka, which was identified in Cruz das Almas for the first time at the end of the second half of 2015, and the occurrence of strong winds during the same year, which was recorded by a local weather station next to the experiment (data not provided). Since this disease recently appeared in the region, the genotypes tested have not been evaluated for its resistance and susceptibility. However, susceptibility could be inferred based on the NLH. Evaluations that quantify disease incidence for the plantain collection should be conducted due to the relevance of black Sigatoka for this crop.

For the 'number of days from planting to harvest - NPH', the plantains did not exhibit behavioral differences (Table 2). While working with plantains, Faria et al. (2010) reported that the cultivar D'Angola' took 309 days to start flowering during the first cycle. Seydou et al. (2017) observed a similar average value (302 days) for four types of plantains in the southern part of Côte d'Ivoire; however, Alvarez et al. (2011), under conditions in Mexico, observed a value of 334 days for the first cycle of the cultivar 'Curare Enano'. These values are lower than those observed in the present study (average of 408.43 for the first cycle) (Table 2).

Bunch mass had an average of $16.26 \mathrm{~kg}$ and 'Red Yade' $(23.76 \mathrm{~kg})$, 'Chifre de Vaca' (23.40 kg) and 'Pinha' (20.01 kg), were notable (Table 2). For the genotype 'D'Angola', this was $14.47 \mathrm{~kg}$, which is similar to what was observed by Faria et al. (2010) in Guanambi. Based on the results, it is possible to identify shorter genotypes that produce more than 'D'Angola' (e.g., 'Red Yad'), which are good candidates to recommend to farmers.

Shaibu et al. (2012), in a humid zone in Nigeria, worked with the plantain FHIA 21 and observed an average bunch mass of $26.03 \mathrm{~kg}$ for the first cycle; a value that is above what was observed in the present study $(22.34$ $\mathrm{kg}$ ). Annor et al. (2016) worked with plantains in Ghana and observed a bunch weight of 22.7 and $22.6 \mathrm{~kg}$ for FHIA 19 and FHIA 20, respectively, which is similar to the plantains evaluated in Cruz das Almas, Brazil.

The number of hands (NHS) and total number of fruits per bunch (NFB) had averages of 7.04 and 53.78, respectively (Table 2). For the number of hands, the genotypes 'Chifre de Vaca', 'Red Yad', 'Curare Enano' and 'Terra Anã Branca', are notable. Kamira et al. (2016), in the region of the Congo, and Venegas et al. (2011), in Mexico, observed a value of 6.70 hands per bunch for the cultivar 'Curare Enano', and Cortazar et al. (2017), in Ecuador, observed an average of 4.5 hands per bunch for the same genotype, which are all lower values compared to the results in the present work (7.50 hands per bunch). 'D'Angola' had the same number of hands per bunch (6.50) compared to Faria et al. (2010) and Ferris et al. (1999). The highest NFB value observed was for the genotype Red Yad' (98.40), followed by 'Pinha', 'Chifre de Vaca' and 'Terra Sem Nome'. The cultivar 'D'angola' had 36.90 fruits per bunch, which is similar to what was found by Faria et al. (2010) in Guanambi (BA) and Ferris et al. (1999) in Uganda. 
In relation to the length and diameter of the fruits, the averages varied from $23.80 \mathrm{~cm}$ to $4.36 \mathrm{~cm}$, respectively (Table 2). Fruit length is used for classification purposes and is a characteristic of great importance for the improvement of plantains (FARIA et al., 2010). Annor et al. (2016) evaluated fruit length for the genotypes FHIA 19 e FHIA 20, which had lower values compared to the 10 genotypes studied in Cruz das Almas, Brazil. For Cortazar et al. (2017), in Ecuador, data for fruit length and diameter of the genotype Curare Enano were similar compared to the present study. In contrast, Kamira et al. (2016) evaluated the hybrid FHIA 21 and observed an average of $23.2 \mathrm{~cm}$ for the length of the fruits. The ANOVA of the five physicochemical characteristics revealed that the source of variation of the 'genotypes' was not significantly different, except for 'Ratio'. The 'genotypes vs. cycles' interaction was only significant for 'Thickness of the peel', showing that, on average, there was no behavioral difference between the plantains of the first and second production cycle (Table 3).

Table 3. Averages of nine physicochemical characteristics for ten plantain genotypes measured during two production cycles.

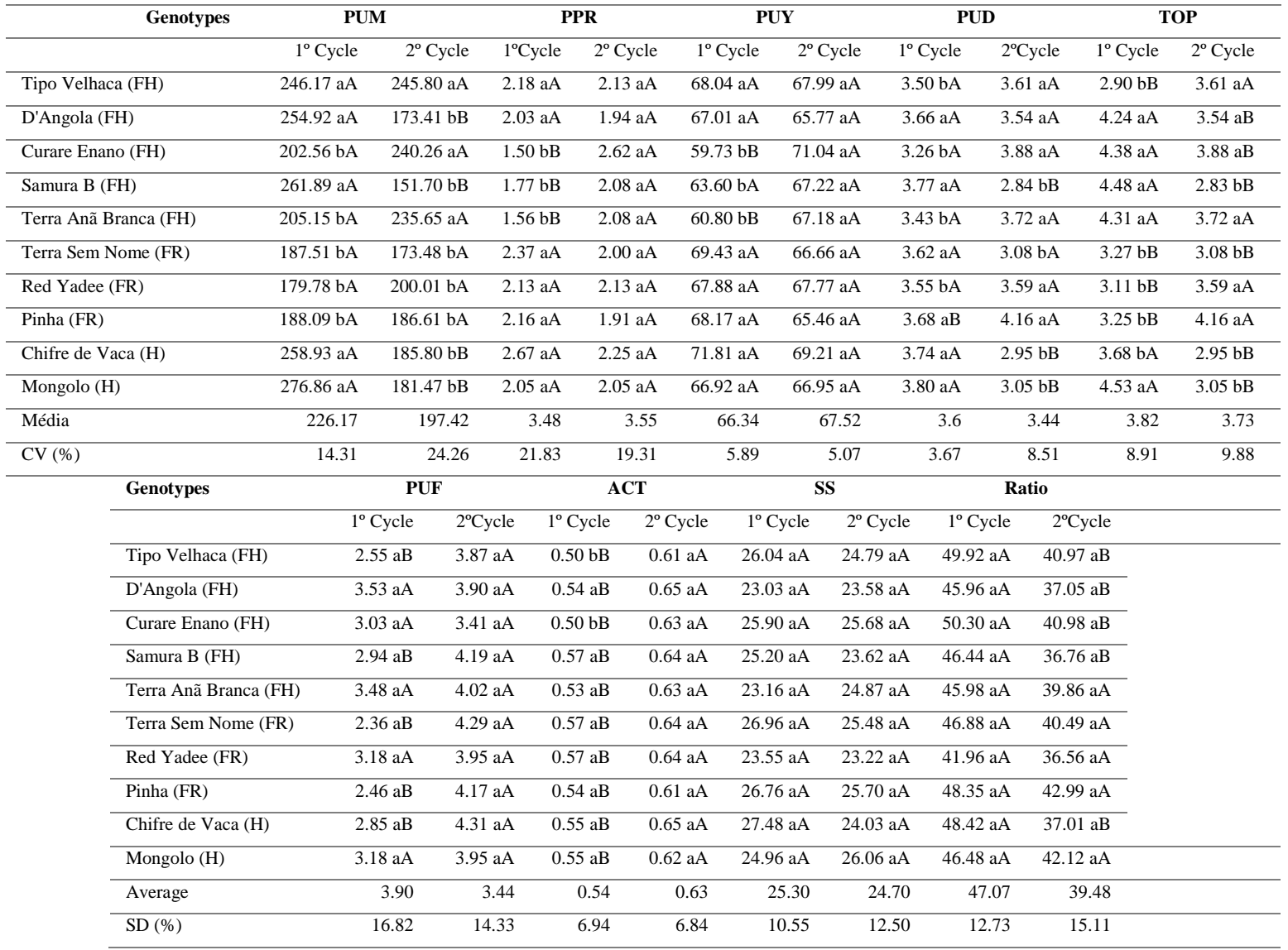

Pulp mass (PUM- g); pulp / peel ratio (PPR- \%); pulp yield (PUY- \%); pulp diameter (PUD- cm); thickness of the peel (TOP - mm); pulp firmness (PUF - LB); malic acid (ATC); soluble solids (SS - ${ }^{\circ}$ Brix) and ratio (RAT). Standard variation (SD). Averages followed by the same uppercase letters in the horizontal and lowercase letters in the vertical comprise a statistically homogenous group and do not differ among themselves based on the Scott \& Knott test, respectively, at 5\% probability. False horn (FH), French (FR), Horn (H). MS (Mean Square) * and **, significant at 1 and $5 \%$ probability by the F-test.

For the PUF, TIA, SS and ratio characteristics, a similar behavior was observed among the 10 plantain genotypes. Considering that ' $\mathrm{D}$ 'Angola' is one of the most used cultivars by Brazilian farmers, the other nine genotypes, on average, have the same quality parameters, allowing for greater sensory acceptability by consumers. 'Thickness of the peel,' can be a component of resistance to transport and storage because the thicker the peel the more resistant the fruit. Most of the genotypes presented values similar to those observed for the cultivar 'D'Angola', notably 'Pinha' and 'Curare Enano'. The dendrogram showing genetic 
dissimilarity based on the combined analysis (agronomic, physicochemical and ISSR data) was obtained using the Ward-MLM method (Figure 1).

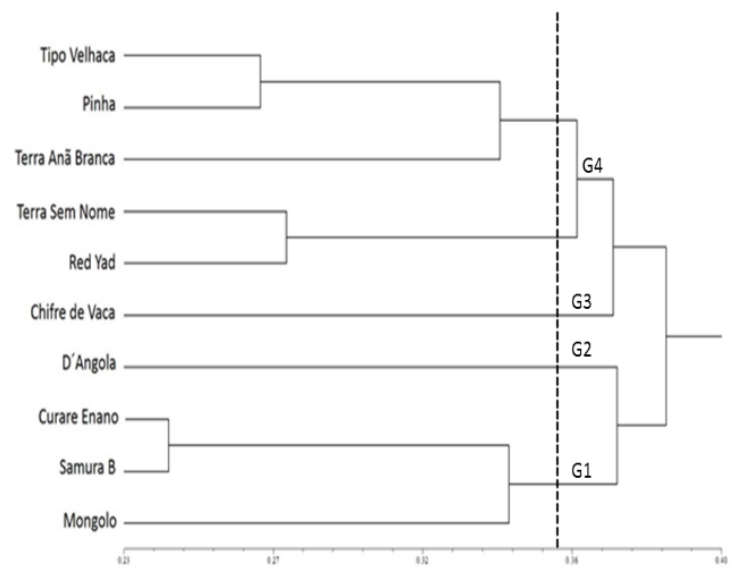

Figure 1. Genetic diversity among 10 plantain genotypes integrating agronomic, physicochemical and molecular data using Gower's algorithm.

The cophenetic correlation value was high $(\mathrm{r}=0.84, \mathrm{p}<0.0001,10.000$ permutations $)$ and adequate, since values of $\mathrm{r} \geq 0.56$ are considered ideal, which reflects agreement with the genetic similarity values (Vaz Patto et al., 2004). To define the ideal number of groups, various cutoff points were tested, including the melting point, with highest leap and the average genetic dissimilarity among the genotypes (average of the matrix). Thus, the average of the matrix was the one that best fit the objective of the present study. Group 1 (G1) comprised genotypes 'Curare Enano', 'Samura B' and 'Mongolo', G2 and G3 comprised only D'Angola' and 'Chifre de Vaca', respectively, and G4 comprised five resistant genotypes (Figure 1). It was not possible to identify a grouping tendency based on the type of plantain (FC, CH or FR), since genotypes of different groups formed the same clusters. Based on these results, it is inferred that the genetic base of the plantains is narrow, which suggests a common origin for the genotypes.

Crouch et al. (2000) conducted a comparative analysis of phenotypic data and RAPD markers for 76 plantain accessions maintained at the IITA germplasm collection in Nigeria. Based on the results, the authors concluded that the genetic base of this subgroup is narrow and that the evolution of these plants occurred through the accumulation of somatic mutations of a small group of ancestors. Working with the same collection, Ude et al. (2003) used AFLP markers to quantify the genetic variability and concluded that these markers have greater discriminatory power for plantain accessions compared to RAPD markers. Noyer et al. (2005) characterized 30 plantain accessions from the CARBAP collection (Cameroon) and encountered results that corroborate Crouch et al. (2000) and Onguso et al. (2004).

Agoreyo et al. (2008) compared plantains used by farmers in Jamaica and Nigeria. In general, the Nigerian plantains were more similar to each other than those from Jamaica; a fact that reinforces the hypothesis of a common origin of this germplasm in the African continent. In the case of Jamaica, according to the authors, it is likely that the genotypes introduced had more contrasting agronomic characteristics, which is reflected in the lower similarity among these plants.

\section{CONCLUSION}

In the present work, different groups of plantains ( $\mathrm{FC}, \mathrm{FR}$ and $\mathrm{CH}$ ) were evaluated and genetic variability was identified, with respect to phenotypic characteristics, both within and among the groups. Therefore, it is inferred that even when restricted, the variability present among the 10 accessions will allow improvement strategies for crosses with diploids resistant to the main pests and diseases to produce new hybrids with agronomic and sensory characteristics aligned with the main requirements and demands of producers and the consumer market. 


\section{ACKNOWLEDGEMENTS}

The authors would like to thank FAPESB for the master's fellowship awarded to the first author and CNPq for the financial support of the project.

\section{REFERENCES}

Agoreyo BO, Golden KD, Brown SE (2008). Analysis of genetic variability among plantain cultivars (Musa paradisiaca L.) using arbitrarily primed PCR technique. African Journal of Biotech. 7(8): 1041-1045. https://doi.org/10.1007/978-3-642-60441-6 21

Alvarez HJC, Venegas FS, Chaves VA (2011). Caracterización agronómica del plátano ‘cv' “Curare Enano” bajo manejo no convencional en Apatzingán Michoacán, México. CienciAgro. 2: 253-260. https://doi.org/10.17151/luaz.2015.41.11

Amorim EP, Santos-Serejo JA, Amorim VBO, Ferreira CF, et al. (2013). Banana breeding at Embrapa cassava and fruits. Acta Hortic. 986: 171-176. https://doi.org/10.17660/actahortic.2013.986.18

Annor GA, Asamoah-Bonti P, Sakyi-Dawson E (2016). Fruit physical characteristics, proximate, mineral and starch characterization of FHIA 19 and FHIA 20 plantain and FHIA 03 cooking banana hybrids. SpringerPlus. 5: 796. https://doi.org/10.1186/s40064-016-2465-1

AOAC - Association of Official Analytical Chemists Official methods of analysis. 16th ed., AOAC, Arlington. p. $850,1997$.

Arantes AM, Donato SLR, Silva TS, Filho VAR, et al. (2017). Agronomic evaluation of banana plants in three production cycles in southwestern state of Bahia. Rev. Bras. de Frutic. 39 (1): 1-12. https://doi.org/10.1590/0100-29452017990

Borges CV, Amorim EP, Amorim VBO, Ramlov F, et al. (2014). Characterization of metabolic profile of banana genotypes, aiming at biofortified Musa spp. cultivars. Food Chem. 145: 496-504. https://doi.org/10.1016/j.foodchem.2013.08.041

Castañeda NEN, Alves GSC, Almeida RM, Amorim EP, et al. (2017). Gene expression analysis in Musa acuminata during compatible interactions with Meloidogyne incognita. Annals of Bot. 119 (5): 915-930.

Cortazar SMU, Wolof DE, Gonzales IA (2017). Effect of plant density on growth and yield in Barraganete plantain AAB cv. Curare Enano for a single harvest cutting in Provincia de Los Rios, Ecuador. Acta agronômica 66 (3): $2367-372$. https://doi.org/10.15446/acag.v66n3.52198

Crouch HK, Masen S, Vuylsteke DR, Ortiz R (2000). Comparative analysis of phenotypic and genotypic diversity among plantain landraces (Musa spp., AAB group). Theor. Appl. Genet. 101(7): 1056-1065. https://doi.org/10.1007/s001220051580

Dadzie BK Orchard JE (1997). Routine Post-Harvest Screening of Banana/Plantain Hybrids:Criteria and Methods. Inibap Technical Guidelines, Inibap, Montpellier, France. 16,

Doyle JJ and Doyle JL (1990). Isolation of plant DNA from fresh tissue. Focus. 12(1): 13-15.

FAO. Food and Agriculture Organization of the United Nations. Disponível em: http://www.faostat.fao.org/site/340/default.aspx.

Faria HC, Donato SLR, Pereira MCT, Silva SO (2010). Avaliação fitotecnia de bananeiras tipo terra sob irrigação em condições semiáridas. Ciência Agrotecnologia 34(4).

Ferris RSB, Ortiz R, Vuylsteke D (1999). Fruit quality evaluation of plantains, plantain hybrids, and cooking bananas. Postharvest Biology and Tech. 3: 73-80.https://doi.org/10.1016/s0925-5214(98)00067-2 
Kamira M, Ntamwira J, Sivirihuama C, Ocimatil W, et al. (2016). Agronomic performance of local and introduced plantains, dessert, cooking and beer bananas (Musa spp.) across different altitude and soil conditions in eastern Democratic Republic of Congo. African Jour. of Agric. Res. 11(43): 4313-4332. https://doi.org/10.5897/ajar2016.11424

Noyer JL, Tomekpe K, Bouet A, Baurens A, et al. (2005). A new image of plantain diversity assessed by SSR, AFLP and MSAP markers. Genetica. 124:61-69. https://doi.org/10.1007/s10709-004-7319-Z

Onguso JM, Kahangi EM, Ndiritu DW, Mizutani F (2004). Genetic characterization of cultivated bananas and plantains in Kenya by RAPD markers. Scien. Hort. 99: 9-20. https://doi.org/10.1016/s0304-4238(03)00082-7

Seydou T, Elisée ALDG, Mamadou C, Leonard OS, et al. (2017). Agronomic Performance of Plantain Cultivars (Musa spp.) in Efficient Mixing Situation for the Control of Black Sigatoka in Southern Côte d'Ivoire. Asian Jour. of Plant Pathol. 11:1-9. https://doi.org/10.3923/ajppaj.2017.1.9

Shaibu AA, Maji EA, Ogburia MN (2012). Yield evaluation of plantain and banana landraces and hybrids in humid agro ecological zone of Nigeria. Jour. of Agric. Res. and Dev. 2(3): 074-079.

Silva PRO, Jesus ON, Bragança CAD, Haddad F, et al. (2016). Development of a thematic collection of Musa spp accessions using SCAR markers for preventive breeding against Fusarium oxysporum f. sp cubense tropical race 4. Gen. and Mol. Res. 15(1): 15017765. https://doi.org/10.4238/gmr.15017765

Tripathi L, Babirye A, Roderick H, Tripathi JN, et al. (2015). Field resistance of transgenic plantain to nematodes has potential for future African food security. Scient. Rep. 5:8127. https://doi.org/10.1038/srep08127

Ude G, Pillay M, Ogundiwin E, Tenkouano A (2003). Genetic diversity in an African plantain core collection using AFLP and RAPD markers. Theor. Appl. Genet. 107:248-255. https://doi.org/10.1007/s00122-003-1246-8

Vaz Patto MC, Satovic Z, Pêgo S, Fevereiro P (2004). Assessing the genetic diversity of Portuguese maize germoplasm using microsatellite markers. Euphytica. 137(1): 63-72. https://doi.org/10.1023/b:euph.0000040503.48448.97

Venegas FS, Alvarez HJC, Chaves VA (2011). Caracterización agronómica del 'cv' “Enano Gigante” michoacán, méxico. Cienci. Agro. 2 : 335-340. 